\title{
Yield response of African leafy vegetables to nitrogen, phosphorus and potassium: The case of Brassica rapa $L$. subsp. chinensis and Solanum retroflexum Dun."
}

\author{
W van Averbeke*, KA Juma and TE Tshikalange \\ Centre for Organic and Smallholder Agriculture, Department of Crop Sciences, Tshwane University of Technology, \\ Private Bag X680, Pretoria 0001, South Africa
}

\begin{abstract}
In this study the growth and yield response of Solanum retroflexum Dun. (nightshade) and Brassica rapa L. subsp. chinensis (non-heading Chinese cabbage) to N, P and K availability in the soil and the interaction effects of these three nutrients were determined by means of pot experiments in a greenhouse. S. retroflexum was most sensitive to the availability of nitrogen in the soil. Sufficient nitrogen needed to be available to achieve optimum growth but adding too much adversely affected biomass production, suggesting a fairly narrow optimum range for nitrogen availability. The production of the crop was also dependent on the adequate availability of phosphorus and potassium but any adverse effects due to excess availability were less distinct than for nitrogen. In the case of B. rapa subsp. chinensis, an optimum availability range was identified for $\mathrm{N}$ and $\mathrm{K}$ and a critical level of availability for $\mathrm{P}$. The decline in biomass production caused by adding $\mathrm{N}$ in excess of the optimum was reversed by applying both $\mathrm{P}$ and $\mathrm{K}$ at rates that were in excess of the respective optima.
\end{abstract}

Keywords: Solanum retroflexum Dun., Brassica rapa L. subsp. chinensis, nightshade, non-heading Chinese cabbage, nutrient response, nitrogen, phosphorus, potassium, optimum application rates

\section{Introduction}

Solanum retroflexum Dun. (nightshade) is a species indigenous to South Africa (Grabandt, 1985; Schippers, 2002), which forms part of the $S$. nigrum complex. This complex contains a range of leafy vegetable species that are harvested from the wild or cultivated by rural people in Africa (Edmonds and Chweya, 1997). In South Africa, cultivation of $S$. retroflexum is a recent development and at this stage limited to the Vhembe District of the Limpopo Province (Van Averbeke and Juma, 2006). Brassica rapa L. subsp. chinensis (non-heading Chinese cabbage) is an indigenised vegetable in the northern parts of South Africa. In the Vhembe District, several rustic land-races of $B$. rapa subsp. chinensis are being cultivated, but the land-race called dabadaba in Tshivenda is one of the two most commonly grown (Tshikalange and Van Averbeke, 2006). The analysis of the irrigated smallholder production systems of these two leafy vegetables in Vhembe identified a great deal of variability in the rates at which nitrogen $(\mathrm{N})$, phosphorus $(\mathrm{P})$ and potassium $(\mathrm{K})$ were applied by producers (Van Averbeke and Juma, 2006; Tshikalange and Van Averbeke, 2006). Optimum crop growth and yield depend on adequate availability of the different plant nutrients, but the application of fertilisers also contributes significantly to the variable costs of production. For example, Van Averbeke and Khosa (2004) reported that on average the application of fertilisers accounted for about $40 \%$ of the total variable costs that

\# Revised version. Originally presented at the International Symposium on the Nutritional Value and Water Use of Indigenous Crops for Improved Livelihoods held on 19 and 20 September 2006 at the University of Pretoria in Pretoria, South Africa

* To whom all correspondence should be addressed.

푱 +2712 382 5777; fax: +2712 382 5869;

e-mail: vanaverbekew@tut.ac.za smallholders at Dzindi Irrigation Scheme incurred when producing $S$. retroflexum and B. rapa subsp. chinensis.

Only a limited number of plant nutrient response studies involving species of the $S$. nigrum complex have been conducted (Table 1), but none of these involved $S$. retroflexum. Generally, these studies demonstrated positive effects of fertiliser application on the growth and yield of these crops and provided an indication of optimum application rates for nitrogen $(N)$, phosphorus $(\mathrm{P})$ and potassium $(\mathrm{K})$ for species in this complex.

\begin{tabular}{|c|c|c|c|c|}
\hline \multicolumn{5}{|c|}{$\begin{array}{l}\text { TABLE 1 } \\
\text { Optimum application rates of nitrogen, phosphorus and } \\
\text { potassium for selected species of the Solanum nigrum } \\
\text { complex (after Merinyo (1996); Shang'a (1996); Chweya } \\
\text { (1997) and AVRDC (2004)) }\end{array}$} \\
\hline \multirow[t]{2}{*}{ Species } & \multirow{2}{*}{$\begin{array}{c}\text { Spacing } \\
\left(\mathrm{m}^{2} \text { plant }^{-1}\right)\end{array}$} & $\mathbf{N}$ & $\mathbf{P}$ & $\mathbf{K}$ \\
\hline & & \multicolumn{3}{|c|}{$\left(\mathrm{kg} \mathrm{ha}^{-1}\right)$} \\
\hline S. villosum & 0.08 & 149 & 40 & 40 \\
\hline S. americanum & 0.24 & 149 & 40 & 40 \\
\hline S. pseudonigrum & 0.09 & 200 & - & - \\
\hline S. nigrum & - & 150 & - & - \\
\hline S. nigrum & 0.25 & 200 & - & - \\
\hline
\end{tabular}

Research results documenting the response of $B$. rapa subsp. chinensis to N, P and K-availability are also limited, at least in the English language. Yoshizawa et al. (1981) determined the effect of nitrogen application rate on the yield of the Chinese cabbage cultivars AVRDC 58 and Yuon-Pao 2, but no research results documenting the response of $B$. rapa subsp. chinensis to $\mathrm{P}$ and $\mathrm{K}$ availability were retrieved. $\mathrm{N}, \mathrm{P}$ and $\mathrm{K}$ application rates recommended for other Brassica species (Hartman et al., 1985; FSSA, 2003; Schippers, 2002) suggest that in the case of low fertility soils, application of 100 to $260 \mathrm{~kg} \mathrm{~N} \cdot \mathrm{ha}^{-1}, 100$ 
to $205 \mathrm{~kg} \mathrm{P} \cdot \mathrm{ha}^{-1}$ and 160 to $205 \mathrm{~kg} \mathrm{~K} \cdot \mathrm{ha}^{-1}$ may be necessary to achieve optimum yield.

The high variability in the application rates of fertilisers used by smallholders in the production of $S$. retroflexum and $B$. rapa subsp. chinensis and the dearth of information on the way these two crops respond to the availability of these three major plant nutrients prompted the current investigation, which involved a series of pot experiments in which the response of the two crops to N, P and K availability was assessed. The objectives of this study were to determine the growth and yield response of the two crops to different levels of N, P and $K$ availability in the soil, to determine the interaction effects of these three nutrients and to obtain preliminary information on the application rates of the three nutrients that are required for optimum growth and yield.

\section{Materials and methods}

\section{Materials}

The soil used in the pot experiments was supplied by JL Coetzer cc in Pretoria. It was excavated in Swartspruit west of Pretoria and consisted of the subsoil of a soil of the Hutton Hayfield family (Soil Classification Working Group, 1991). The soil was a yellowish red (5YR 4/5, dry), low fertility, sandy clay loam with a $\mathrm{pH}$ (Water) of 5.9 and a $\mathrm{pH}(\mathrm{KCl})$ of 4.9 . The soil contained $2.5 \mathrm{mg} \mathrm{NH}_{4}^{+}-\mathrm{N}$ and $8.8 \mathrm{mg} \mathrm{NO}{ }_{3}^{-}-\mathrm{N} \cdot \mathrm{kg}^{-1}, 2 \mathrm{mg} \mathrm{P} \cdot \mathrm{kg}^{-1}$ (Bray 1) and $32 \mathrm{mg} \mathrm{K} \cdot \mathrm{kg}^{-1}$ (1 M ammonium acetate extraction) in its natural state. The soil was screened through a $2 \mathrm{~mm}$ mesh sieve before being used in the pot studies. The gravimetric water content of the soil was $14.3 \%$ at field capacity (FC), $5.2 \%$ at permanent wilting point (PWP) when $S$. retroflexum was used as the test crop and $6.7 \%$ when $B$. rapa subsp. chinensis was used.

The experiments were conducted in a greenhouse that had a wet-wall and two fans to control maximum temperature but no heating to control minimum temperature. The fans engaged thermostatically as soon as the temperature in the greenhouse reached $25^{\circ} \mathrm{C}$.

The experiments were conducted in plastic pots with a content of $7 \ell$ and five perforations at the bottom for drainage. The chemical fertilisers limestone ammonium nitrate $(28 \% \mathrm{~N})$, single super phosphate $(10.5 \% \mathrm{P})$ and potassium chloride $(50 \% \mathrm{~K})$ which had been ground to pass through an $0.5 \mathrm{~mm}$ sieve were used to apply N, P and $\mathrm{K}$ to the soil in the pots.

The $S$. retroflexum seed that was used in the experiments was obtained from Ms MT Ratshitanga, a small-scale vegetable seed producer in Ngulumbi, Vhembe District, Limpopo Province. The seed of the dabadaba land-race of $B$. rapa subsp. chinensis was obtained from a single plant grown at the Tshwane University of Technology in Pretoria.

Biomass measurements were made using a portable electronic scale (Scout ${ }^{\circledR}$ Pro SPU123 manufactured by Ohaus) with a capacity of $120 \mathrm{~g}$ and an accuracy of $0.001 \mathrm{~g}$.

\section{Experimental procedures}

\section{General procedures}

Four pot experiments were conducted for each of the two crops. In the first three experiments the response of the crops to different rates of added N, P and K was separately evaluated. In the fourth experiment, the interaction effects among the three nutrients were determined.

In all experiments the pots were filled with a homogenised mixture of $8 \mathrm{~kg}$ of soil (air-dry mass) and the relevant amounts of the chemical fertilisers. A filter paper was placed at the bottom of the pots to avoid soil losses through the drainage holes during filling. The amount of nutrients applied per pot were obtained by converting the application rate of elemental nutrient per ha to the amount per plant using the spacing of $0.177 \mathrm{~m}^{2}$ plant ${ }^{-1}$ (56 497 plants $^{-1} a^{-1}$ ) for $S$. retroflexum and the spacing of $0.195 \mathrm{~m}^{2}$ plant $^{-1}$ (51 282 plants $\cdot \mathrm{a}^{-1}$ ) for $B$. rapa subsp. chinensis. For each of the two crops these were reportedly the average spacings used by smallholders at Dzindi Irrigation Scheme (Van Averbeke and Khosa, 2004).

In all experiments the soil in the pots was brought to field capacity one week before planting to allow the fertilisers to react with the soil. The pots were then covered with cling wrap to prevent water from evaporating. $S$. retroflexum was planted at a density of 10 seeds per pot using an off-centre planting pattern, whereafter the pots were again covered with cling wrap until the seedlings emerged. Thinning was undertaken at the $3^{\text {rd }}$ leaf stage and only a single healthy seedling was retained in each pot. The planting and thinning procedure used in the $B$. rapa subsp. chinensis experiments was the same as for $S$. retroflexum, but only 5 seeds were planted per pot and thinning occurred at the $6^{\text {th }}$ leaf stage.

The available water content in the pots was kept in excess of $50 \%$ of the total plant-available water capacity (FC - PWP) throughout the duration of the experiments. Drainage water that had collected in the drainage trays was returned to the corresponding pot before each watering, but this rarely happened.

The economic yield was used as the indicator of plant response for each crop. This involved the measurement of fresh above-ground biomass for $S$. retroflexum and the fresh mass of marketable leaves for $B$. rapa subsp. chinensis. Oven-dry mass measurements were also made by drying the fresh biomass in a forced-draught oven at $70^{\circ} \mathrm{C}$ until constant mass. In the experiments involving $S$. retroflexum, the crop was harvested three times. The first harvest commenced about 8 weeks after seedling emergence and subsequent harvests followed at intervals of approximately 3 weeks. At harvest the entire shoot was removed by cutting the plant stem $5 \mathrm{~cm}$ above the soil surface, as recommended by Edmonds and Chweya (1997). In the experiments with $B$. rapa subsp. chinensis the marketable leaves were harvested in stages in accordance with farmer practice (Tshikalange and Van Averbeke, 2006). The $5^{\text {th }}$ true leaf, considered by farmers as the first marketable leaf, was harvested when the plants had reached the 8-leaf stage. One week later the $6^{\text {th }}$ leaf was harvested, and the remaining marketable leaves were harvested when the peduncle had commenced elongation in $50 \%$ of the plants.

\section{Single nutrient experiments}

In the single nutrient experiments with $S$. retroflexum, the first experiment involved seven application rates of $\mathrm{N}$ covering a range of 0 to $300 \mathrm{~kg} \mathrm{~N} \cdot \mathrm{ha}^{-1}$, whilst applying $\mathrm{P}$ and $\mathrm{K}$ at the rates of $50 \mathrm{~kg} \mathrm{P} \cdot \mathrm{ha}^{-1}$ and $150 \mathrm{~kg} \mathrm{~K} \cdot \mathrm{ha}^{-1}$. The second involved seven application rates of $\mathrm{P}$ covering a range of 0 to $200 \mathrm{~kg} P \cdot h a^{-1}$ whilst ensuring optimum availability of $\mathrm{N}$ as determined in the first experiment and supplying $\mathrm{K}$ as in the first experiment. The $3^{\text {rd }}$ experiment had eight application rates of $\mathrm{K}$ covering a range of 0 to $200 \mathrm{~kg} \mathrm{~K} \cdot \mathrm{ha}^{-1}$, whilst ensuring optimum availability of $\mathrm{N}$ and $\mathrm{P}$ as identified in the first and second experiment. Planting dates, number of replications and the temperature range experienced over the duration of these three experiments are shown in Table 2. 
In the single nutrient experiments with $B$. rapa subsp. chinensis, the first experiment involved additions of nitrogen at rates ranging between 0 and $300 \mathrm{~kg} \mathrm{~N} \cdot h \mathrm{~h}^{-1}$, whilst applying $\mathrm{P}$ and $\mathrm{K}$ at $300 \mathrm{~kg} \cdot \mathrm{ha}^{-1}$ each. These high rates of $\mathrm{P}$ and $\mathrm{K}$ application were opted for because of the very low $\mathrm{P}$ and $\mathrm{K}$ content of the soil and the high $\mathrm{P}$ and $\mathrm{K}$ requirements of other Brassica species. The second experiment determined the response of the crop to the availability of $\mathrm{P}$ and involved additions of $\mathrm{P}$ at rates ranging between 0 and $400 \mathrm{~kg} P \cdot \mathrm{ha}^{-1}$ whilst ensuring an optimum availability of $\mathrm{N}$ as determined in the first experiment and supplying $\mathrm{K}$ as in the first experiment. The third experiment determined the response of the crop to the availability of $\mathrm{K}$ and involved additions of $\mathrm{K}$ at rates ranging between 0 and $400 \mathrm{~kg}$ $\mathrm{K} \cdot \mathrm{ha}^{-1}$. Planting dates, number of replications and the temperature range experienced over the duration of these three experiments are shown in Table 2.

\section{Factorial experiments}

In the NPK factorial experiments with each of the crops the three nutrients were applied at four rates, which included a control (application withheld), the optimum rate determined in the single nutrient experiments, half the optimum rate, and a rate in excess of the optimum. Planting dates, number of replications and the temperature range experienced over the duration of the two experiments are shown in Table 2.

\section{Statistical analysis}

Analysis of variance using the SAS statistical package was performed to test for treatment effects (SAS Institute Inc, 2000). Following the recommendation of Dr B Eisenberg, the consulting biometrician at TUT at the time of the study, the Duncan's Multiple Range Test $(p \leq 0.05)$ was used to separate treatment means obtained in the single nutrient experiments and the Fisher's LSD test $(p \leq 0.05)$ to separate the treatment means obtained in the factorial experiments.

\section{Results and discussion}

\section{Results}

\section{Solanum retroflexum}

The results obtained in the three single nutrient experiments with $S$. retroflexum are presented in Table 3.

Increased $\mathrm{N}$ application rates increased total fresh and ovendry above-ground biomass of $S$. retroflexum until the rate of 150 $\mathrm{kg} \mathrm{N} \cdot \mathrm{ha}^{-1}$, although the difference between the application rates

\begin{tabular}{|l|c|c|c|c|}
\hline \multirow{2}{*}{$\begin{array}{c}\text { Planting date, number of replications and temperature range for the different pot } \\
\text { experiments with Solanum retroflexum Dun. and Brassica rapa L. subsp. chinensis }\end{array}$} \\
\hline Experiment & Planting date & $\begin{array}{c}\text { Number of } \\
\text { replications }\end{array}$ & $\begin{array}{c}\text { Absolute mini- } \\
\text { mum temperature } \\
\text { ( }{ }^{\circ} \text { C) }\end{array}$ & $\begin{array}{c}\text { Absolute maxi- } \\
\text { mum temperature } \\
\left({ }^{\circ} \mathrm{C}\right)\end{array}$ \\
\cline { 2 - 5 } & & \multicolumn{5}{|c|}{ Solanum retroflexum } \\
\hline N single nutrient & $23 / 09 / 2004$ & 10 & 19 & 29 \\
\hline P single nutrient & $22 / 01 / 2005$ & 10 & 18 & 28 \\
\hline K single nutrient & $19 / 04 / 2005$ & 10 & 9 & 27 \\
\hline NPK factorial & $19 / 01 / 2006$ & 5 & 22 & 29 \\
\hline & & Brassica rapa subsp. chinensis \\
\hline N single nutrient & $23 / 09 / 2004$ & 10 & 19 & 28 \\
\hline P single nutrient & $26 / 03 / 2005$ & 7 & 16 & 26 \\
\hline K single nutrient & $02 / 06 / 2005$ & 10 & 9 & 14 \\
\hline NPK factorial & $14 / 08 / 2005$ & 5 & \multicolumn{5}{|c|}{} \\
\hline
\end{tabular}

\begin{tabular}{|c|c|c|c|c|c|c|c|c|}
\hline \multicolumn{9}{|c|}{$\begin{array}{l}\text { TABLE } 3 \\
\begin{array}{l}\text { Effects of application rate of nitrogen, phosphorus and potassium on total fresh and oven-dry } \\
\text { above-ground biomass of Solanum retroflexum Dun. obtained from three harvests }\end{array}\end{array}$} \\
\hline \multicolumn{3}{|c|}{$\mathrm{N}$ experiment } & \multicolumn{3}{|c|}{ P experiment } & \multicolumn{3}{|c|}{ K experiment } \\
\hline $\begin{array}{l}\text { Application } \\
\text { rate of } \mathrm{N}\end{array}$ & $\begin{array}{l}\text { Total fresh } \\
\text { above- } \\
\text { ground } \\
\text { biomass }\end{array}$ & $\begin{array}{l}\text { Total oven- } \\
\text { dry above- } \\
\text { ground } \\
\text { biomass }\end{array}$ & $\begin{array}{l}\text { Application } \\
\text { rate of } P\end{array}$ & $\begin{array}{l}\text { Total fresh } \\
\text { above- } \\
\text { ground } \\
\text { biomass }\end{array}$ & $\begin{array}{l}\text { Total oven- } \\
\text { dry above- } \\
\text { ground } \\
\text { biomass }\end{array}$ & $\begin{array}{l}\text { Application } \\
\text { rate of } K\end{array}$ & $\begin{array}{l}\text { Total fresh } \\
\text { above- } \\
\text { ground } \\
\text { biomass }\end{array}$ & $\begin{array}{l}\text { Total oven- } \\
\text { dry above- } \\
\text { ground } \\
\text { biomass }\end{array}$ \\
\hline$\left(\mathrm{kg} \mathrm{N} \mathrm{ha}^{-1}\right)$ & \multicolumn{2}{|c|}{$\left(\right.$ g pot $\left.^{-1}\right)$} & $\left(k^{\prime} P a^{-1}\right)$ & \multicolumn{2}{|c|}{$\left(g^{1} \operatorname{pot}^{-1}\right)$} & $\left(\mathrm{kg} \mathrm{K} \mathrm{ha}^{-1}\right)$ & \multicolumn{2}{|c|}{$\left(\mathrm{g} \mathrm{pot}^{-1}\right)$} \\
\hline 0 & $16.7_{e}$ & $2.5_{d}$ & 0 & $15.6_{e}$ & $1.77_{e}$ & 0 & $43.8_{e}$ & $5.2_{d}$ \\
\hline 50 & $164.3_{d}$ & $16.5_{c}$ & 17 & $69.1_{d}$ & $6.5_{d}$ & 15 & $141.3_{d}$ & $16.8_{c}$ \\
\hline 100 & $271.2_{\mathrm{ab}}$ & $25.5_{\mathrm{b}}$ & 34 & $136.5_{c}$ & $11.8_{c}$ & 30 & $182.9_{c}$ & $20.9_{\mathrm{b}}$ \\
\hline 150 & $306.3 \mathrm{a}$ & $32.2_{a}$ & 50 & $175.9_{\mathrm{b}}$ & $14.6_{\mathrm{b}}$ & 45 & $194.1_{\mathrm{bc}}$ & $21.4_{\mathrm{b}}$ \\
\hline 200 & $305.9_{a}$ & $32.5_{a}$ & 100 & $209.3_{\mathrm{a}}$ & $17.2_{a}$ & 60 & $237.4_{a b}$ & $25.6_{a}$ \\
\hline 250 & $246.6_{b c}$ & $26.6_{b}^{a}$ & 150 & $188.9_{\mathrm{ab}}$ & $13.7_{b c}$ & 100 & 255.4 & $27.0_{a}^{a}$ \\
\hline 300 & $209.7_{c}$ & $23.1_{b}$ & 200 & $156.4_{b c}$ & $13.6_{\mathrm{bc}}$ & 150 & $256.5_{a}$ & $25.9_{a}$ \\
\hline & & & & & & 200 & $214.3_{\mathrm{b}}$ & $21.9_{\mathrm{b}}^{\mathrm{a}}$ \\
\hline Mean & 217.2 & 22.7 & & 135.6 & 11.3 & & 190.7 & 20.6 \\
\hline $\mathrm{CV} \%$ & 13.0 & 15.0 & & 19.0 & 19.4 & & 18.8 & 18.9 \\
\hline
\end{tabular}

For each of the three nutrients, treatment means followed by different letters differed significantly $(p \leq 0.05)$. 
of $100 \mathrm{~kg} \mathrm{~N} \cdot \mathrm{ha}^{-1}$ and $150 \mathrm{~kg} \mathrm{~N} \cdot \mathrm{ha}^{-1}$ was not statistically significant $(p \leq 0.05)$ in the case of fresh biomass. At an application rate of $200 \mathrm{~kg} \mathrm{~N} \cdot \mathrm{ha}^{-1}$ both fresh and oven-dry biomasses were practically identical to those at $150 \mathrm{~kg} \mathrm{~N} \cdot \mathrm{ha}^{-1}$. At N application rates of higher than $200 \mathrm{~kg} \mathrm{~N} \cdot \mathrm{ha}^{-1}$ both fresh and oven-dry biomass declined sharply below the maximum values, reached at 150 and $200 \mathrm{~kg} \mathrm{~N}^{-1}$.

Increased $\mathrm{P}$ application rates increased total fresh and ovendry above-ground biomass of $S$. retroflexum until the rate of 100

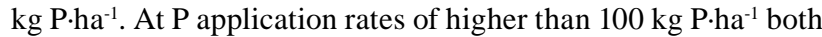
fresh and oven-dry biomass declined sharply below the maximum values, reached at $100 \mathrm{~kg} P \cdot \mathrm{ha}^{-1}$.

Increased $\mathrm{K}$ application rates increased total fresh and ovendry above-ground biomass of $S$. retroflexum until the rate of 100

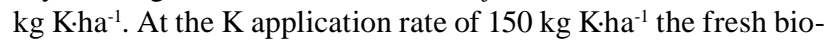
mass was practically identical to that at $100 \mathrm{~kg} \mathrm{~K} \cdot \mathrm{ha}^{-1}$. Although

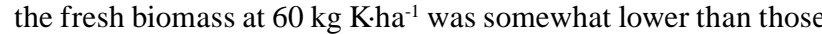
at 100 and $150 \mathrm{~kg} \mathrm{~K} \cdot \mathrm{ha}^{-1}$, the differences were not statistically significant $(p \leq 0.05)$.

By means of quadratic regression curves fitted to the fresh above-ground biomass data obtained in the three single nutrient experiments application rates of $196 \mathrm{~kg} \mathrm{~N} \cdot \mathrm{ha}^{-1}, 122 \mathrm{~kg} \mathrm{P} \cdot \mathrm{ha}^{-1}$ and $125 \mathrm{~kg} \mathrm{~K} \cdot \mathrm{ha}^{-1}$ were identified as optimal for maximum biomass production under experimental greenhouse conditions on this soil that was highly deficient in all three these major nutrients, especially $\mathrm{P}$ and $\mathrm{K}$.

Table 4 shows the results obtained in the NPK factorial experiment using total fresh above-ground biomass as the biomass response indicator.

Statistically, the main effects, the three first order inter- actions and the second order interactions were all highly significant $(p<0.0001)$. As was observed in the single nutrient experiments, exclusion of any of the three nutrients had a strong negative effect of fresh above-ground biomass production. In the case of $\mathrm{N}$, the optimum level tended to be lower $(\mathrm{N} 1=98 \mathrm{~kg}$ $\mathrm{N} \cdot \mathrm{ha}^{-1}$ ) than that identified in the $\mathrm{N}$ experiment (N2 $=196 \mathrm{~kg}$ $\mathrm{N} \cdot \mathrm{ha}^{-1}$ ). As was the case in the $\mathrm{N}$ experiment adding $\mathrm{N}$ in excess of the optimum (N1) had a negative effect on biomass production. This effect was amplified by a strong NxP interaction, with high P applications (P2, P3) combined with high N (N2, N3) applications in most cases leading to yield reductions - in some cases very sharp reductions.

At the low N level (N1) there were no differences in biomass production between the different $\mathrm{P}$ levels applied. At the higher $\mathrm{N}$ levels (N2, N3) high P applications (P2, P3) in most cases led to yield reductions - in some cases very sharp reductions - as indicated above. Thus, indications were that applying $\mathrm{P}$ at a rate of $61 \mathrm{~kg} \mathrm{P} \cdot \mathrm{ha}^{-1}$ was optimal (P1), which was also less than the optimum identified in the $\mathrm{P}$ experiment $\left(\mathrm{P} 2=122 \mathrm{~kg} \mathrm{P} \cdot \mathrm{ha}^{-1}\right)$. At the lowest $\mathrm{N}$ level (N1) this would represent an economic optimum, while at the higher $\mathrm{N}$ levels this would represent the $\mathrm{P}$ application giving maximum biomass production.

The results largely confirmed the $\mathrm{K}$ application for maximum fresh above-ground biomass production (K2 $=125 \mathrm{~kg}$ $\mathrm{K} \cdot \mathrm{ha}^{-1}$ ) identified in the K experiment, but the differences in fresh above-ground biomass production between the three $\mathrm{K}$ levels were very small and not statistically significant $(p \leq 0.05)$.

Similar results were obtained when using oven-dry above-ground biomass as the indicator of plant response (not shown).

\begin{tabular}{|c|c|c|c|c|c|}
\hline \multicolumn{6}{|c|}{$\begin{array}{c}\text { TABLE } 4 \\
\text { Interaction effects of nitrogen, phosphorus and potassium application } \\
\text { rates on the total fresh above-ground biomass of Solanum retroflexum } \\
\text { Dun. obtained from three harvests }\end{array}$} \\
\hline \multicolumn{6}{|c|}{ Nutrient application rates } \\
\hline \multirow[t]{4}{*}{ K } & \multirow[t]{4}{*}{$\mathbf{P}$} & \multicolumn{4}{|c|}{$\mathbf{N}$} \\
\hline & & No & N1 & N2 & N3 \\
\hline & & \multicolumn{4}{|c|}{ Total fresh above-ground biomass } \\
\hline & & \multicolumn{4}{|c|}{$\left(\right.$ g pot $\left.^{-1}\right)$} \\
\hline \multirow[t]{4}{*}{ K0 } & P0 & $4.66_{\mathrm{f}}$ & $9.83_{\mathrm{f}}$ & $5.33_{\mathrm{f}}$ & $3.47_{\mathrm{f}}$ \\
\hline & P1 & $37.20_{f}$ & $132.10_{\text {ed }}$ & $113.04_{\text {ed }}$ & $87.98_{e}$ \\
\hline & $\mathrm{P} 2$ & $30.24_{f}$ & $148.57_{d}$ & $87.58_{\text {ef }}$ & $72.82_{\text {ef }}$ \\
\hline & P3 & $45.48_{\text {ef }}$ & $148.19_{\text {ed }}$ & $79.31_{\mathrm{ef}}$ & $77.81_{\mathrm{ef}}$ \\
\hline \multirow[t]{4}{*}{ K1 } & P0 & $11.37_{\mathrm{f}}$ & $16.77_{\mathrm{f}}$ & $3.44_{f}$ & $2.39_{f}$ \\
\hline & P1 & $27.75_{f}$ & $313.89_{a b}$ & $282.03_{\mathrm{b}}$ & $244.80_{\mathrm{bc}}$ \\
\hline & $\mathrm{P} 2$ & $29.89_{f}$ & $307.08_{\mathrm{ab}}$ & $138.54_{\text {ed }}$ & $167.59_{\mathrm{cd}}$ \\
\hline & P3 & $47.84_{\text {ef }}$ & $266.36_{b c}$ & 137.87 ed & $176.42_{\mathrm{cd}}$ \\
\hline \multirow[t]{4}{*}{ K2 } & P0 & $6.06_{f}$ & $15.75_{f}$ & $0.59_{\mathrm{f}}$ & $2.92_{f}$ \\
\hline & P1 & $36.10_{f}$ & $339.83_{\mathrm{ab}}$ & $320.08_{\mathrm{ab}}$ & $233.77_{b c}$ \\
\hline & $\mathrm{P} 2$ & $34.54_{f}$ & $283.24_{b}$ & $197.97_{\mathrm{cd}}$ & $206.02_{c}$ \\
\hline & P3 & $33.19_{f}$ & $343.62_{a}$ & $241.34_{b c}$ & $58.78_{\text {ef }}$ \\
\hline \multirow[t]{4}{*}{ K3 } & P0 & $10.88_{f}$ & $14.90_{f}$ & $3.77_{\mathrm{f}}$ & $2.12_{\mathrm{f}}$ \\
\hline & P1 & $26.23_{f}$ & $310.94_{a b}$ & $267.82_{b c}$ & $213.40_{b c}$ \\
\hline & $\mathrm{P} 2$ & $29.70_{f}$ & $310.40_{\mathrm{ab}}$ & $233.04_{b c}$ & $221.677_{b c}$ \\
\hline & P3 & $34.61_{f}$ & $285.65_{\mathrm{ab}}$ & $310.95_{\mathrm{ab}}$ & $109.37_{\text {ed }}$ \\
\hline
\end{tabular}

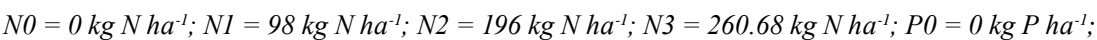

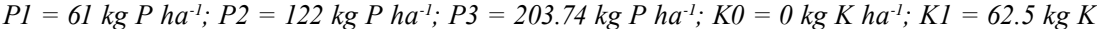

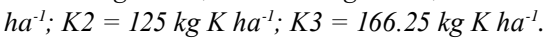

Treatment means followed by different letters differed significantly $(p \leq 0.05)$. 
Table 6 (see next page) shows the treatment means obtained

The results obtained in the three single nutrient experiments are presented in Table 5.

Fresh and oven-dry mass of marketable leaves increased with application rate of $\mathrm{N}$. Although both indicators tended to peak when nitrogen was applied at the rate of $200 \mathrm{~kg} \mathrm{~N} \cdot \mathrm{ha}^{-1}$, there were no statistically significant differences in the fresh marketable leaf mass between $\mathrm{N}$ application rates ranging from 100 to $250 \mathrm{~kg} \mathrm{~N} \cdot \mathrm{ha}^{-1}$, suggesting a fairly wide optimum $\mathrm{N}$ availability range. From an economic perspective the lowest application rate in such range would be optimum. There was a tendency for fresh and oven-dry mass of marketable leaves to decline when the application rate exceeded $250 \mathrm{~kg} \mathrm{~N} \cdot \mathrm{ha}^{-1}$.

The trend of the response of $B$. rapa subsp. chinensis to the availability of $\mathrm{P}$ in the soil differed radically from that obtained with Solanum tetroflexum (Tables 3 and 5). In the case of $S$. retroflexum the required $\mathrm{P}$ application rate for maximum yield peaked fairly distinctly at a relatively high application rate of over $100 \mathrm{~kg} \mathrm{P} \cdot \mathrm{ha}^{-1}$, above which rate the yields decreased with increased P application rate (Table 3). In the case of Brassica rapa subsp. chinensis, total fresh and oven-dry mass of marketable leaves increased as $\mathrm{P}$ was added to the soil until the rate of

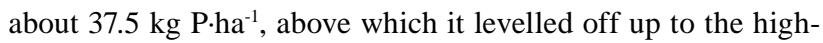
est rate applied of $400 \mathrm{~kg} \mathrm{P} \cdot \mathrm{ha}^{-1}$ (Table 5). This suggests that $\mathrm{P}$ availability only affected the mass of leaves of Brassica rapa subsp. chinensis below some relatively low critical level, which in this experiment was reached when $\mathrm{P}$ was applied at the rate of $37.5 \mathrm{~kg} \mathrm{P} \cdot \mathrm{ha}^{-1}$. This was despite the fact that the soil used in the experiment was highly $\mathrm{P}$ deficient. Once this critical level of $\mathrm{P}$ availability in the soil had been attained, adding more $\mathrm{P}$ had no effect, with the absence of negative responses to extremely high $P$ application rates being noticeable.

The response of Brassica rapa subsp. chinensis to K differed from those observed for $\mathrm{N}$ and $\mathrm{P}$ by showing a distinct optimum application rate for maximum yield. Total mass of fresh and oven-dry marketable leaves increased significantly ( $p \leq 0.05)$ as the rate of application of $\mathrm{K}$ was raised up to the rate of $80 \mathrm{~kg}$ $\mathrm{K}^{\prime} \mathrm{ha}^{-1}$ and declined when this optimum rate was exceeded. in the NxPxK factorial experiment, using total fresh mass of marketable leaves as the biomass response indicator.

Statistically, the main effects, the three first order interaction effects and the second order interaction effects were all highly significant $(p<0.0001)$. Treatments in which one or more of the three nutrients were not applied failed to produce marketable leaves (Table 6). The highest mean mass of marketable leaves was obtained when $\mathrm{N}$ was applied at the rate of $188 \mathrm{~kg}$ $\mathrm{N} \cdot h \mathrm{a}^{-1}$ and $\mathrm{P}$ and $\mathrm{K}$ each at the rate of $100 \mathrm{~kg} \cdot \mathrm{ha}^{-1}$. This particular treatment (N2P2K2) more or less represented the combination of the three optimum application rates identified in the previous single-nutrient experiments. However, the yield differences between this treatment and several others were very small and not statistically significant $(p \leq 0.05)$.

In the NxPxK factorial experiment (Table 6) there was no significant reduction $(p \leq 0.05)$ in the fresh mass of marketable leaves within any NxK combination when the application rate of $\mathrm{P}$ was increased to $200 \mathrm{~kg} \mathrm{P} \cdot \mathrm{ha}^{-1}$ (P3) or reduced to $50 \mathrm{~kg}$ P·ha-1 (P1), confirming the trend with regard to response to $P$ found in the single nutrient experiments.

In the NxPxK factorial experiment (Table 6), there was no significant reduction $(p \leq 0.05)$ in the fresh mass of marketable leaves when the application rate of $\mathrm{K}$ was raised from $100 \mathrm{~kg}$ $\mathrm{K}^{\prime} \cdot \mathrm{a}^{-1}$ (K2) to $200 \mathrm{~kg} \mathrm{~K} \cdot \mathrm{ha}^{-1}$ (K3) as long as P was applied at the rate of $50 \mathrm{~kg} \mathrm{P} \cdot \mathrm{ha}^{-1}(\mathrm{P} 1)$ or higher and $\mathrm{N}$ at the rate of $188 \mathrm{~kg} \cdot \mathrm{ha}^{-1}$

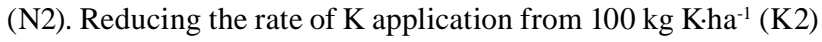

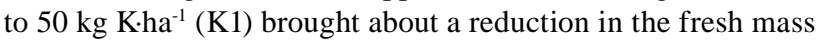
of marketable leaves except when $\mathrm{P}$ was applied at the highest rate $(\mathrm{P} 3)$.

Increasing the rate of $\mathrm{N}$ to $376 \mathrm{~kg} \mathrm{~N} \cdot \mathrm{ha}^{-1}$ (N3) reduced $(p \leq 0.05)$ mean mass of marketable leaves relative to the N2P2K2 treatment only when the application rates of $\mathrm{P}$ and $\mathrm{K}$ were less than $100 \mathrm{~kg} \cdot \mathrm{ha}^{-1}$ (P2 and K2), but when the application rate of $\mathrm{K}$ was raised to $200 \mathrm{~kg} \cdot \mathrm{ha}^{-1}$ (K3), the application rate of $\mathrm{P}$ had to be increased to $200 \mathrm{~kg} \mathrm{P} \cdot \mathrm{ha}^{-1}$ (P3) also to avoid a reduction $(p \leq 0.05)$ in the fresh mass of marketable leaves. Applying $\mathrm{N}$ at the rate of $94 \mathrm{~kg} \mathrm{~N} \cdot \mathrm{ha}^{-1}(\mathrm{~N} 1)$ reduced $(p \leq 0.05)$ the fresh mass of marketable leaves except when $\mathrm{K}$ was applied at the rate of

\begin{tabular}{|c|c|c|c|c|c|c|c|c|}
\hline \multicolumn{9}{|c|}{$\begin{array}{c}\text { TABLE } 5 \\
\begin{array}{c}\text { Effects of application rate of nitrogen, phosphorus and potassium on the fresh and oven-dry mass } \\
\text { of marketable leaves of dabadaba (Brassica rapa L. subsp. chinensis) in pots }\end{array}\end{array}$} \\
\hline \multicolumn{3}{|c|}{$\mathrm{N}$ experiment } & \multicolumn{3}{|c|}{ P experiment } & \multicolumn{3}{|c|}{$\mathrm{K}$ experiment } \\
\hline $\begin{array}{l}\text { Application } \\
\text { rate of } N\end{array}$ & $\begin{array}{c}\begin{array}{c}\text { Fresh mass } \\
\text { of market- } \\
\text { able leaves }\end{array} \\
\end{array}$ & $\begin{array}{l}\text { Oven-dry } \\
\text { mass of } \\
\text { marketable } \\
\text { leaves }\end{array}$ & $\begin{array}{l}\text { Application } \\
\text { rate of } P\end{array}$ & $\begin{array}{c}\text { Fresh mass } \\
\text { of market- } \\
\text { able leaves }\end{array}$ & $\begin{array}{l}\text { Oven-dry } \\
\text { mass of } \\
\text { marketable } \\
\text { leaves }\end{array}$ & $\begin{array}{l}\text { Application } \\
\text { rate of } K\end{array}$ & 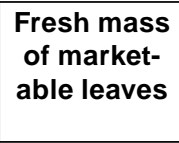 & $\begin{array}{l}\text { Oven-dry } \\
\text { mass of } \\
\text { marketable } \\
\text { leaves }\end{array}$ \\
\hline$\left(\mathrm{kg} \mathrm{N}^{\prime} \mathrm{ha}^{-1}\right)$ & \multicolumn{2}{|c|}{$\left(g \cdot\right.$ pot $\left.^{-1}\right)$} & $\left(k^{\prime} P \cdot h a^{-1}\right)$ & \multicolumn{2}{|c|}{$\left(g \cdot p^{-1}\right)$} & $\left(\mathrm{kg} \mathrm{K}^{\prime} \mathrm{ha}^{-1}\right)$ & \multicolumn{2}{|c|}{$\left(g \cdot \operatorname{pot}^{-1}\right)$} \\
\hline 0 & $0.00_{c}$ & $0.00_{c}$ & 0.0 & $0.00_{e}$ & $0.00_{\mathrm{e}}$ & 0 & $0.00_{\mathrm{f}}$ & $0.00_{\mathrm{f}}$ \\
\hline 50 & $113.00_{\mathrm{b}}$ & $11.50_{b}$ & 12.5 & $95.86_{d}$ & $4.57_{d}$ & 10 & $127.10_{e}$ & $10.00_{e}$ \\
\hline 100 & $139.80_{\mathrm{ab}}$ & $12.91_{b}$ & 25.0 & $230.86_{c}$ & $10.99_{b c}$ & 20 & $190.50_{d}$ & $16.27^{d}$ \\
\hline 150 & $140.90_{\mathrm{ab}}$ & $12.92_{\mathrm{b}}$ & 37.5 & $306.14 \mathrm{a}$ & $13.42_{\mathrm{ab}}$ & 40 & $241.10_{b c}$ & $20.60_{c}$ \\
\hline 200 & $162.10_{a}$ & $16.02_{\mathrm{a}}$ & 50.0 & $291.71_{\mathrm{ab}}$ & $12.32_{\mathrm{bc}}$ & 60 & $254.70_{b}$ & $23.33_{b}$ \\
\hline 250 & $153.20_{a}$ & $14.74_{\mathrm{ab}}$ & 75.0 & $285.14_{a b}$ & $13.04_{b c}$ & 80 & $278.80_{a}$ & $25.46_{a}$ \\
\hline 300 & $128.00_{\mathrm{b}}^{\mathrm{a}}$ & $12.59_{b}$ & 100.0 & $313.57_{a}$ & $13.03_{\mathrm{bc}}$ & 100 & $256.50_{\mathrm{b}}^{\mathrm{a}}$ & $22.42_{b c}^{a}$ \\
\hline & & & 200.0 & $267.14_{b}$ & $11.25_{c}$ & 200 & $241.90_{b c}$ & $20.01_{c}$ \\
\hline & & & 300.0 & $285.14_{a b}$ & $12.95_{b c}$ & 400 & $231.60_{c}$ & $18.05_{\mathrm{cd}}$ \\
\hline & & & 400.0 & $308.42_{a}$ & $15.26_{a}$ & & & \\
\hline Mean & 119.59 & 11.52 & & $238.40^{a}$ & 10.68 & & 202.47 & 17.35 \\
\hline CV\% & 22.39 & 24.37 & & 14.81 & 18.14 & & 12.29 & 13.70 \\
\hline
\end{tabular}

For each of the three nutrients, treatment means followed by different letters differed significantly $(p \leq 0.05)$ 


\begin{tabular}{|c|c|c|c|c|c|}
\hline \multicolumn{6}{|c|}{$\begin{array}{c}\text { TABLE } 6 \\
\text { Interaction effects of nitrogen, phosphorus and potassium application } \\
\text { rates on the total fresh mass of marketable leaves of dabadaba (Brassica } \\
\text { rapa L. subsp. chinensis) }\end{array}$} \\
\hline \multicolumn{6}{|c|}{ Nutrient application rates } \\
\hline \multirow[t]{4}{*}{$\mathbf{K}$} & \multirow[t]{4}{*}{$\mathbf{P}$} & \multicolumn{4}{|c|}{$\mathbf{N}$} \\
\hline & & No & N1 & N2 & N3 \\
\hline & & \multicolumn{4}{|c|}{ Total mass of fresh marketable leaves } \\
\hline & & \multicolumn{4}{|c|}{$\left(\right.$ g pot $\left.^{-1}\right)$} \\
\hline \multirow[t]{4}{*}{ K0 } & P0 & 0 & 0 & 0 & 0 \\
\hline & P1 & 0 & 0 & 0 & 0 \\
\hline & P2 & 0 & 0 & 0 & 0 \\
\hline & P3 & 0 & 0 & 0 & 0 \\
\hline \multirow[t]{4}{*}{ K1 } & P0 & 0 & 0 & 0 & 0 \\
\hline & P1 & 0 & $186.4_{b c}$ & $183.4_{\mathrm{bc}}$ & $142.6_{c}$ \\
\hline & $\mathrm{P} 2$ & 0 & $185.6_{\mathrm{bc}}$ & $168.0_{c}$ & $171.0_{\mathrm{bc}}$ \\
\hline & P3 & 0 & $192.0_{\mathrm{ab}}$ & $198.0_{\mathrm{ab}}$ & $168.0_{c}$ \\
\hline \multirow[t]{4}{*}{ K2 } & P0 & 0 & 0 & 0 & 0 \\
\hline & P1 & 0 & $186.8_{\mathrm{bc}}$ & $215.2_{\mathrm{ab}}$ & $172.8_{\mathrm{bc}}$ \\
\hline & P2 & 0 & $196.4_{\mathrm{ab}}$ & $222.8_{a}$ & $200.4_{a b}$ \\
\hline & P3 & 0 & $197.0_{\mathrm{ab}}^{\mathrm{ab}}$ & $207.2^{\mathrm{a}}$ & $200.8_{\mathrm{ab}}$ \\
\hline \multirow[t]{4}{*}{ K3 } & P0 & 0 & 0 & 0 & 0 \\
\hline & P1 & 0 & $177.0_{\mathrm{bc}}$ & $208.4_{\text {ab }}$ & $177.2_{\mathrm{bc}}$ \\
\hline & P2 & 0 & $184.2_{\mathrm{bc}}$ & $205.8_{\mathrm{ab}}$ & $182.0_{\mathrm{bc}}$ \\
\hline & P3 & 0 & $172.8_{\mathrm{bc}}$ & $203.4_{a b}$ & $203.2_{\mathrm{ab}}$ \\
\hline
\end{tabular}

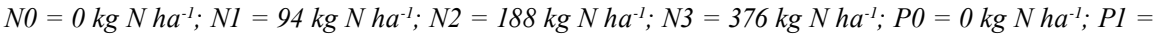

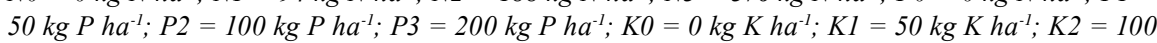

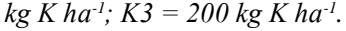

Treatment means followed by different letters differed significantly $(p \leq 0.05)$.

$100 \mathrm{~kg} \mathrm{~K} \cdot \mathrm{ha}^{-1}$ (K2) and P at the rate of $100 \mathrm{~kg}$ P·ha- ${ }^{-1}$ or higher (P2 and P3). Similar results were obtained when using total ovendry mass of marketable leaves as the indicator of plant response (not shown).

\section{Discussion}

The results of this study indicate that both crops were sensitive to the availability of nitrogen in the soil, but the magnitude of their responses differed widely, as shown in the single nutrient experiments (Tables 3 and 5). Solanum retroflexum responded much stronger to different $\mathrm{N}$ levels than Brassica rapa subsp. chinensis and also much stronger than to differences in either $\mathrm{P}$ or $\mathrm{K}$ levels. Brassica rapa subsp. chinensis responded less strongly to different $\mathrm{N}$ levels than Solanum retroflexum, and also less strongly to $\mathrm{N}$ than to either $\mathrm{P}$ or $\mathrm{K}$. To optimise their economic yield sufficient nitrogen had to be applied to the soil, but adding too much had a distinctly negative effect on biomass production in both crops. Negative effects of excessive application of $\mathrm{N}$ on biomass production has been documented for several crops (Robert et al., 1989), including S. nigrum (Merinyo, 1996; Chweya, 1997). Nkoa et al. (2003) suggest that biomass reductions caused by excessive $\mathrm{N}$ applications may be the result of osmotic imbalances due to $\mathrm{N}$ accumulation in plant tissues. The optimum application rate of $\mathrm{N}$ identified for Solanum retroflexum in this study was lower than the optimum rate reported for S. nigrum by Merinyo (1996) and Chewya (1997), viz. $150 \mathrm{~kg} \mathrm{~N} \cdot \mathrm{ha}^{-1}$ in combination with the application of farm yard manure at the rate of 10 thha $^{-1}$ and $200 \mathrm{~kg} \mathrm{~N} \cdot \mathrm{ha}^{-1}$ respectively. The optimum $\mathrm{N}$ application rate for B. rapa subsp. chinensis identified in the present study falls within the optimum range identified for other Brassica species grown in low fertility soils (Hartman et al., 1985; FSSA, 2003; Schippers, 2002). For B. rapa subsp. chinensis specifically Yoshizawa et al. (1981) reported the application rate of $120 \mathrm{~kg}$ $\mathrm{N} \cdot \mathrm{ha}^{-1}$ as optimal. This value was obtained in a field experiment that was conducted on a fertile soil, whereas in this study the results were obtained in pot experiments using a low fertility soil. The results of the two factorial experiments showed that the decline in biomass production caused by adding $\mathrm{N}$ in excess of the optimum was to an extent counteracted by applying both $\mathrm{P}$ and $\mathrm{K}$ at rates that were in excess of their respective optima, particularly in the case of $B$. rapa subsp. chinensis. This indicates that balance in the availability of the three nutrients is also important.

The differences between the two crops regarding response to different $\mathrm{P}$ levels may have major practical significance. The reponse patterns of $B$. rapa L. subsp. chinensis especially may be very important to follow up. $S$. retroflexum showed the wellknown pattern reported by other researchers (e.g. Laker, 2005) for other crops, with increased yield with increased $\mathrm{P}$ applications up to an optimum level and above that reduction in yield at higher P levels. Biomass reductions associated with excessive application of $\mathrm{P}$ have been linked to reduced availability of micronutrients (Hopkins and Elsworth, 2003). No research findings documenting the response of S. nigrum to $\mathrm{P}$ availability were retrieved.

The responses of Brassica rapa L. subsp. chinensis to different $\mathrm{P}$ levels are in two respects important: In the first place it reached maximum yield at a low $\mathrm{P}$ application rate $(37.5 \mathrm{~kg}$ $\left.\mathrm{P} \cdot \mathrm{ha}^{-1}\right)$, despite the very low plant-available $\mathrm{P}$ content of the soil (Table 3). This indicates that this crop feeds very strongly on $P$, 
and can possibly utilise $\mathrm{P}$ sources that are unavailable to most crops. Since P is by far the most expensive of the three major plant nutrients (per kg nutrient), such crop may provide a relative economic advantage for small scale farmers on $\mathrm{P}$ deficient soils. Secondly, the fact that it showed no yield reduction at very high $\mathrm{P}$ levels in either the single nutrient experiment or factorial experiment, indicates that it may be a very useful crop on soils on which $\mathrm{P}$ has been built up to excessive levels and on which other crops consequently perform badly. Such situations are not uncommon on old commercial crop fields (Laker, 2005). In the process it can on such soils also "mine" down P to levels that are optimum for other crops.

Biomass reductions associated with excessive application of $\mathrm{K}$ to highly weathered, highly leached soils with low base nutrient cation ( $\mathrm{K}, \mathrm{Mg}, \mathrm{Ca})$ contents, such as found in the present study, have been associated with imbalances in the $\mathrm{K}: \mathrm{Mg}$ and $\mathrm{K}$ : Ca ratios (Jones, 2003). No research findings documenting the response of $S$. nigrum to K availability were retrieved. The optimum rate for $\mathrm{K}$ indentified in the present study falls within the optimum range identified for other Brassica species grown in low fertility soils (Hartman et al., 1985; FSSA, 2003; Schippers, 2002).

It needs pointing out that pot experiments provide only an initial indication of the nutrient requirements of a crop (Tening et al., 1995; Cox et al., 1999). They have the advantage over field experiments in that they enable the elimination of a great deal of environmental variability (Rowell, 1994) but their disadvantage is that they employ small quantities of soil, resulting in the containment and concentration of plant roots, creating conditions that are different from those found in the field. Although fairly large quantities of soil were used in this study, the volume of soil available to the plants was only about $10 \%$ of that expected to be available to plants growing in the field. To develop fertiliser recommendations for use by farmers, field experiments that take the nutrient status of the soil into account need to be conducted.

\section{Conclusions and recommendations}

The results of this study suggest that optimising soil nitrogen availability is the most critical nutrient management concern in the production of $S$. retroflexum and $B$. rapa subsp. chinensis. Sufficient nitrogen needs to be available in the soil to achieve optimum growth, but adding too much nitrogen adversely affects biomass production. Considering that smallholders in Vhembe produce $S$. retroflexum and $B$. rapa subsp. chinensis under irrigation, which increases the likelihood of nitrogen losses due to leaching, maintaining optimum availability of $\mathrm{N}$ in field soils throughout the growing season is expected to be difficult to achieve. The use of split application of $\mathrm{N}$, which is common practice among smallholders at present (Juma, 2006; Tshikalange, 2006), is likely to be the appropriate strategy to achieve this objective but this needs to be investigated. Production of the two crops was also shown to be dependent on the adequate availability of phosphorus and potassium, but the adverse effects caused by applying these two nutrients in excess of the rate at which biomass production reached an optimum were less distinct than for nitrogen. The findings of this study suggest that growers stand to benefit financially from optimising fertiliser application rates in the production of $S$. retroflexum and $B$. rapa subsp. chinensis, but field experiments are needed to identify these rates.

\section{Acknowledgement}

This article is based on work done in terms of a research project that is being supported financially by the Tshwane University of Technology, the South African Water Research Commission (WRC Project No. K5/1464//4 and WRC Project No. K5/1579//4) and the National Research Foundation (GUN2069585) but the authors accept full liability for any opinions, findings, conclusions or recommendations contained in this article.

\section{References}

AVRDC (Asian Vegetables Research and Development Centre) (2004) Evaluation of Variation in Plant Population for Yield Adaptation and Horticultural Characteristics of Promising Nightshade Lines. AVRDC Report 2003. The World Vegetable Centre, Shanhua. No page numbers.

CHWEYA JA (1997) Genetic enhancement of indigenous vegetable in Kenya. In: Guarino L (ed.) Traditional African Vegetables. Proc. IPGRI Int. Workshop on Genetic Resources of Traditional Vegetable in Africa, University of Nairobi Kenya. International Plant Genetic Resources Institute (IPGRI), Rome. 86-95.

COX AE, JOERN BC, BROUDER SM and GAO D (1999) Plant available potassium assessment with a modified sodium tetraphenylboron method. Soil Sci. Soc. Am. J. 63 902-911.

EDMONDS JM and CHWEYA JA (1997) Black nightshades: Solanum nigrum L. and related species: promoting the conservation and use of underutilized and neglected crops. IPGRI, Rome. [Online]. Available from: http://www.bioversityinternational.org/publications/ pufile.asp?_pub = 337 (Accessed on 22/03/07).

FERTILIZER SOCIETY OF SOUTH AFRICA (FFSA) (2003) Fertilizer Handbook ( ( $^{\text {th }}$ revised edn.) FSSA, Lynnwood. 296 pp.

GRABANDT K (1985) Weeds of Crops and Garden in South Africa. Ciba-Geigy (Pty) Ltd, Johannesburg. 135 pp.

HARTMANN HT, FLOCKER WJ and KOFRANEK AM (1981) Plant Science: Growth and Development and Utilization of Cultivated Plants. Prentice-Hall Inc., Englewood Cliffs. 676 pp.

HOPKINS B and ELLSWORTH J (2003) Phosphorus nutrition in potato production [Online]. Available from: http://www.ag.uidaho.edu/ potato/research/files/volume $\% 2035 /$ vol\%252035 75\%2520Phospho rus\%2520Nutrition.pdf (Accessed on 20/07/2005).

JONES JB (Jr) (2003) Agronomic Handbook: Management of Crops, Soils, and their Fertility. CRC Press, New York. 450 pp.

JUMA KA (2006) Response of Solanum retroflexum Dun. to Nitrogen, Phosphorus and Potassium in Pots. M. Tech. (Agric.) Dissertation, Department of Crop Sciences, Tshwane University of Technology, Pretoria. 138 pp.

LAKER MC (2005) Appropriate plant nutrient management for sustainable agriculture in Southern Africa. Comm. Soil Sci. and Plant Anal. 36 89-106

MERINYO N (1996) Effect of fertilizer and manure on the yield and harvest duration of black nightshade. In: AVRDC/ARP Training reports. A Compilation of Research Reports by Training Scholars on Vegetable Research and Production. AVRDC, Arusha, Kenya. 223-225.

NKOA R, COULOMBE J, DESJARDINS Y and TREMBLAY N (2000) Toward optimisation of growth via nutrient supply phasing: nitrogen phasing increases broccoli (Brassica oleracea var. italica) growth and yield. J. Exp. Bot. 52 821-827.

ROBERT K, HAY M and WALKER AJ (1989) An Introduction to the Physiology of Crop Yield. Longman Scientific \& Technical, Burnt Mill, Harlow, UK. 292 pp.

ROWELL DL (1994) Soil Science: Methods and Application. Longman Group Ltd, London. 350 pp.

SCHIPPERS RR (2002) African Indigenous Vegetables: An Overview of the Cultivated Species. Revised edition. [CD-ROM]. Natural Resources Institute/ACP-EU Technical Center for Agricultural and Rural Cooperation, Chatham. 252 pp.

SHANG'A TA (1996) Effect of nitrogen and spacing on the yield of yellow nightshade. In: AVRDC/ARP Training reports. A Compilation 
of Research Reports by Training Scholars on Vegetable Research and Production. AVRDC, Arusha, Kenya. 120-123.

SOIL CLASSIFICATION WORKING GROUP (1991) Soil Classification: A Taxonomic System for South Africa. Department of Agricultural Development, Pretoria. 257 pp.

STATISTICAL ANALYSIS SOFTWARE INSTITUTE INC (2000) The Statistical Analysis Software $\left(S A S^{\circledR}\right)$ Version 8.08. Statistical package. SAS Institute Inc., Cary, North Carolina.

TENING AS, OMUETIJ JA and TARAWAL GI (1995) Potassium requirements of grass/legume pasture established on selected soils of the sub-humid zone of Nigeria. Comm. Soil Sci. and Plant Anal. 26 2403-2424.

TSHIKALANGE TE (2006) Response of Brassica rapa L. subsp. chinensis to Nitrogen, Phosphorus and Potassium in Pots. M. Tech. (Agric.) Dissertation, Department of Crop Sciences, Tshwane University of Technology, Pretoria. $159 \mathrm{pp}$.

TSHIKALANGE TE and VAN AVERBEKE W (2006) The cultivation of Brassica rapa L. subsp. chinensis in Vhembe, Limpopo Province, South Africa. Int. Symp. on the Nutritional value and Water Use of Indigenous Crops for Improved Livelihoods. Volume of papers (not edited) [CD ROM]. 19-20 September, The Centre for Nutrition, University of Pretoria, Pretoria. No page numbers.

VAN AVERBEKE W and JUMA KA (2006) The cultivation of Solanum retroflexum Dun. in Vhembe, Limpopo Province, South Africa. Proc. Int. Symp. on the Nutritional Value and Water Use of Indigenous Crops for Improved Livelihoods. Volume of papers (not edited) [CD ROM]. 19-20 September, The Centre for Nutrition, University of Pretoria, Pretoria. No page numbers.

VAN AVERBEKE W and KHOSA TB (2004) The Triple-A framework for the analysis of smallholder food commodity chains. In: Proc. $3^{\text {rd }}$ Int. Conf. on Entrepreneurship - Sustainable Globalization. 3-4 November, Pretoria. [CD-ROM]. Tshwane University of Technology, Pretoria, South Africa. 292-299.

YOSHIZAWA T, HUA MA C and ROAN YC (1981) Management of summer Chinese cabbage in Taiwan. In: Talker NS and Griggs TD (eds.) Proc. $1^{\text {st }}$ Int. Symp. on Chinese Cabbage. 31 March-5 April 1980, Tsukuba. Asian Vegetable Research and Development Center Shanhua, Taiwan. 55-60. 